\title{
The characterization of sunburn basalts and their magnetic and petrographic properties
}

\author{
Lucie NOVÁKOVÁ1*, Petr SCHNABL², Joerg BÜCHNER ${ }^{3}$ \\ ${ }^{1}$ Czech Academy of Sciences, Institute of Rock Structure and Mechanics, V Holešovičkách 41, 182 09 Prague 8, Czech Republic; \\ lucie.novakova@irsm.cas.cz \\ ${ }^{2}$ Czech Academy of Sciences, Institute of Geology, Rozvojová 269, 16000 Prague 6, Czech Republic \\ ${ }^{3}$ Senckenberg Museum, Am Museum 1, D-02826 Görlitz, Germany \\ * Corresponding author
}

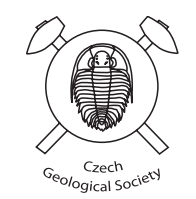

Sunburn texture, a white-grey mottling of dark grey basalts, is frequently found in outcrops around the world. The sunburn basalt is more fractured and less resistant than the fresh one, and so its identification is of interest in all types of basalt quarries.

Three localities were chosen with different types and shapes of volcanic bodies in the Lausitz Volcanic field in the border area of the Czech Republic and Germany (Borská Skalka, Mittelherwigsdorf, Wittgendorf) in order to characterize sunburn lavas and study the petrographic and magnetic changes between fresh massive and sunburn basalts. The sunburn basalts have cracked, disrupted outcrop surfaces where white-grey spots are observed. As seen in thin section, the spots contain mainly analcite, the mineral that is responsible for the sunburn effect. The appearance of analcite is indicated by the enhanced amount of $\mathrm{Al}$ and $\mathrm{Na}$. The whole rock is affected by many cracks that are filled with limonite. Limonite also infiltrates the sunburn spots, which are rich in microcracks.

In the field were measured thirteen profiles perpendicular to the volcanic bodies in order to describe the magnetic properties in situ (magnetic field intensity, inclination and declination values). The intensity of magnetic field and its azimuth change with the distance from the rock. A major change occurs $c .130 \mathrm{~cm}$ away from the wall, which implies that the major cause is at some distance. The changes in magnetic inclination were negligible with the exception of the Borská Skalka site, where standard deviation of the magnetic field was $29.3 \mu \mathrm{T}$, and the standard deviation of the azimuth $78.7^{\circ}$ for the sunburn part. In the laboratory were measured natural magnetic resistivity (NMR) and isothermal remanent magnetization (IRM). The calculated REM (remanent magnetization) parameter averaged $2.0 \%$ for the sunburn parts and $0.8 \%$ for the massive basalt. The sunburn basalts are affected mainly by weathering and hydration that causes changes in petrophysical and magnetic properties. The most prominent changes in all the variables could be seen at Borská Skalka, whose top is exposed to lightnings. Because of the increased conductivity, the sunburn parts become preferred lightning paths and the initial magnetic properties of the basalt can be overprinted by the electrical activity.

Keywords: sunburn, basalt, petrography, weathering, magnetic field, Lausitz Volcanic Field

Received: 31 January 2018; accepted: 30 November 2018; handling editor: B. van Wyk de Vries

The online version of this article (doi: 10.3190/jgeosci. 274) contains supplementary electronic material.

\section{Introduction}

Sunburn texture is a common feature in basaltic rocks, manifested by distinctive small grey-white spots at the outcrop. The effect of the sunburn phenomenon on physical and mechanical parameters of basalts was described by several authors (e.g. Hibsch 1920; Pukall 1939, 1940; Schreiber 1991; Zagożdżon 1998, 2001a, b, 2003; Gisbert et al. 2016). The small ball-like texture, with white or grey spots and cracks on the rock surface highlighted by weathering, is also called "Sonnenbrand" in the German literature (Pukall 1939, 1940; Schreiber 1991). Sunburn is a typical type of basaltic weathering, whose intensity increases towards the subsoil, accompanied by a change from massive columnar basalts to irregular blocks. Sunburns occur exclusively in basalts and are bound to the existence of nepheline, analcite and/or rock glass (Weiher et al. 2007).

Sunburn symptoms (the spots and fine cracking) are caused by chemical and physical weathering. At the initial stage of sunburn development, the so-called "spots" appear as three-dimensional, isometric fair discolourations. Their diameter varies between 10 and $20 \mathrm{~mm}$ (Leppla 1901; Hibsch 1920; Śliwa 1975; Zagożdżon 1998, 2001a, b). Then, a system of irregular "capillary cracks" ("Haarrise" in German literature) develops, usually running between the "spots". The formation of these disjunctions consequently leads to breaking up of the sunburn basalt into debris of smaller fragments (Zagożdżon 2003). Gisbert et al. (2016) stated that the combination of rock temperature and water supply strongly influence the conditions of the development and type of sunburn. 


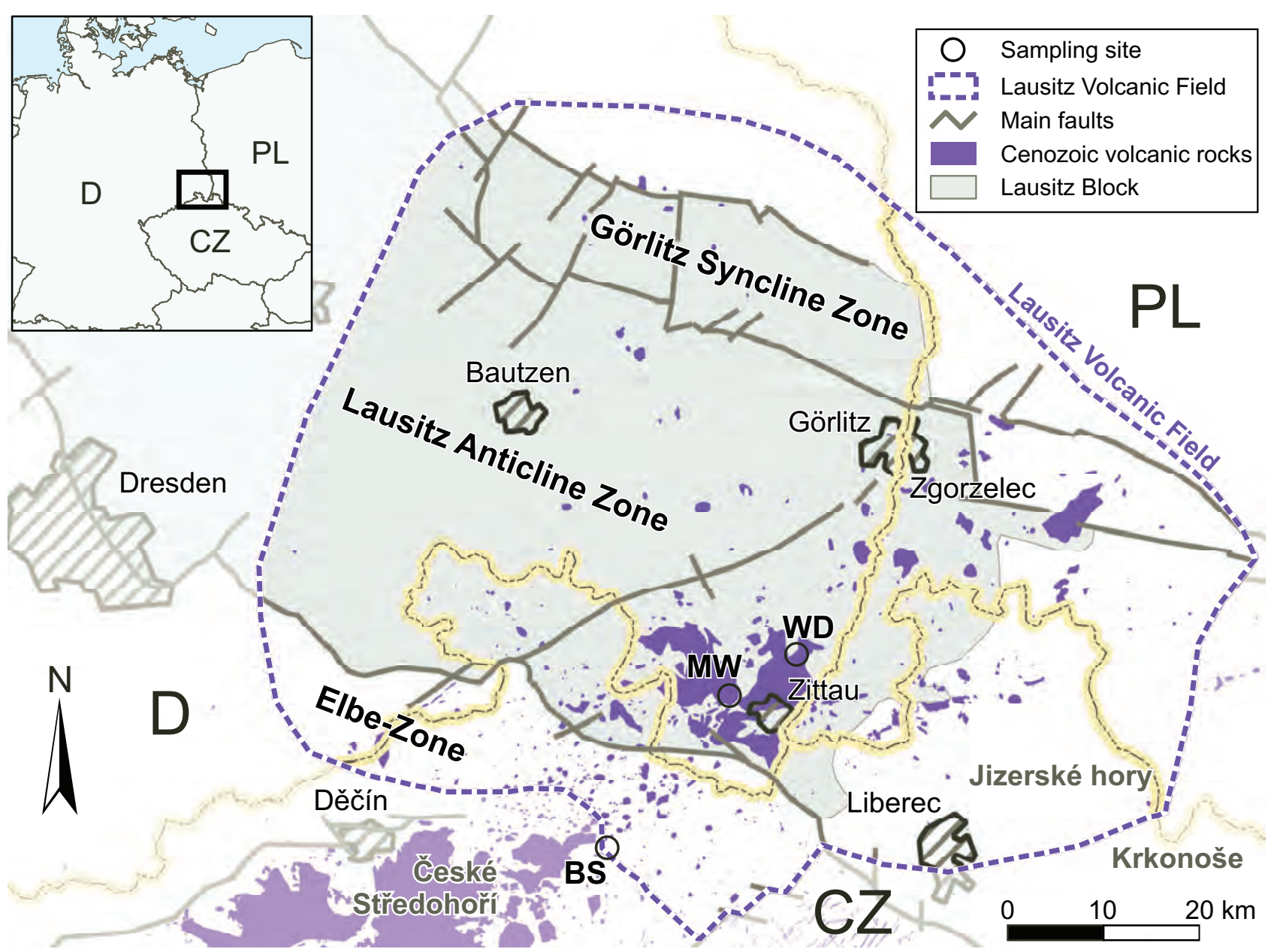

Fig. 1 Geological sketch of the Lausitz Volcanic field (modified after Büchner et al. 2015), BS = Borská Skalka, MW = Mittelherwigsdorf, WD $=$ Wittgendorf.

There are important differences in the magnetic, chemical, and petrophysical properties between massive and sunburn rocks. When the weathering starts, common basalts change into sunburn basalts with analcite and nepheline minerals. These changes in mineralogical compositions modify the mechanical properties of the rocks (Schreiber et al. 1999). The occurrence of sunburn in the rocks is one of the factors excluding these materials from industrial exploitation. Since basalt is commonly used as building material for construction, for highway structures and exposed in cuttings (Kühnel et al. 1994; Vavrová et al. 2002), the sunburn properties are of interest for the constructions planning.

In this paper, we introduce the phenomenon of sunburn basalts and its implications for engineering geology. We explore sunburn basalt and the changes between massive and sunburn parts of basaltic bodies. As the sunburn basalt has a chemical composition different from the massive one, magnetic and petrographic characteristics also change. Therefore, the aim of this work is also to describe the changes in the composition in sunburn basalts by the field and laboratory measurements.

\section{Geological setting}

The study areas are situated within the Lausitz (syn. Lusatian) Volcanic Field (Büchner et al. 2015), at the triple-junction of Poland, Czech Republic and Germany (Fig. 1). The Lausitz Volcanic Field is a part of the Cenozoic Central European Volcanic Province, a $1600 \mathrm{~km}$ long belt of Cenozoic volcanic occurrences c. $300 \mathrm{~km}$ north of the Alpine Front (Wimmenauer 1974; Wedepohl and Baumann 1999; Lustrino and Wilson 2007). In a closer view, the Lausitz Volcanic Field is considered as northeastern prolongation of volcano-tectonic activity of the Ohře Rift (Eger Graben) in northwestern Bohemia (e.g., Ulrych et al. 1999; Cajz 2000; Cajz et al. 2009; Kopecký 2010; Ulrych et al. 2011). This is supported by the distribution of volcanoes showing a southwest-northeast alignment (Fediuk 2003) as well as by the occurrence of Tertiary lignite-bearing basins (Zittau, Berzdorf-Radomierzyce) revealing a geological development similar to that in the Ohře Rift (Büchner et al. 2013). The volcanoes in the Lausitz Volcanic Field 
were fed by alkaline mantle melts and common rocks are alkali basaltoids (nephelinite, basanite, and tephrite) as well as phonolite and trachyte.

The Lausitz bimodal magmatism resulted from melt differentiation in the crust, as supported by evidence from rare intermediate lavas (Büchner et al. 2015). Typical volcanic structures are scoria cones with associated lava lakes, lava flows, and exposed feeder vents, along with maars and lava (crypto) domes. The eruption ages $\left({ }^{40} \mathrm{Ar}-{ }^{39} \mathrm{Ar}\right)$ range $35-27 \mathrm{Ma}$ with a peak between 32 and $29 \mathrm{Ma}$ (Büchner et al. 2015). K-Ar ages are similar, but often a little younger (Pfeiffer et al. 1984; Kaiser and Pilot 1986). Commonly, large parts of volcanoes have been weathered and eroded away, especially the pyroclastic rocks, such as scoriae, breccias, and tuffs. Thus now remain mostly necks, plugs, relicts of lava lakes, flows or domes as well as maar deposits when covered by younger sediments. The volcanoes of the Lausitz Volcanic Field are mainly monogenetic, but polygenetic or complex types are also found (see compilation by Büchner et al. 2015).

In the centre of the Lausitz Volcanic Field, at around the Zittau Basin, where there is the highest density of volcanic structures, it is difficult to reconstruct the former volcano edifices separately, due to the Cenozoic (Neogene and Quaternary) sediment cover. However, in the other parts of Lausitz Volcanic Field, such as in the northern part of the Lausitz Block or the Zittau Mountains south of the Lausitz Block, remnants of individual volcanoes are mostly isolated. From more than 1000 volcanic outcrops in the Lausitz Volcanic Field, c. 530 volcano centres have been mapped (Büchner et al. 2015). In the past few years, detailed investigations of the volcanic formations of the Lausitz Volcanic Field were carried out for some of them (e.g. Lorenz et al. 2003; Suhr et al. 2006; Tietz et al. 2011a, b, 2013; Büchner and Tietz 2012).

\section{Methodology}

\subsection{Petrographic analysis}

Thirteen samples were studied under the optical polarization microscope and scanning electron microscope. Twenty-six thin sections were used - two per sample - cut perpendicular to each other. Thus, internal orientations could be observed in three dimensions. Samples were collected from the same locations where geomagnetic measurements were acquired. In this way we obtained petrographic data in a cross section across the outcrop from fresh massive to sunburn lavas. Scanning electron microscope (JEOL JSM 6510LV, $15 \mathrm{kV}, 69 \mu \mathrm{A}$ ) with EDX detector (Bruker XFlash 410-M) was used to obtain the qualitative analyses of the studied samples.

\subsection{Magnetic analysis}

Field and laboratory measurements of the magnetic properties of both sunburn and massive basalts were made. In the field, we measured thirteen $2.5 \mathrm{~m}$ long magnetic profiles perpendicular to the rock face in order to interpret the disturbances in the magnetic field produced by the volcanic body. A three-axial sensor 520 fluxgate magnetometer (Applied Physics System) was mounted to the 2.6-meter-long aluminium profile, which was attached to a non-magnetic spirit level. The precision of the level was $0.17^{\circ}$. The measuring interval close to the rock was $5 \mathrm{~cm}$ (from the rock surface up to $60 \mathrm{~cm}$ ). Within the distance of $60-250 \mathrm{~cm}$ from the rock, the measuring interval was $10 \mathrm{~cm}$.

The total intensity of magnetic field $(H)$, inclination $(I)$ and magnetic declination $(D)$ (defined by Butler 1992) were calculated as follows:

$$
\begin{aligned}
& H=\sqrt{H_{x}^{2}+H_{y}^{2}+H_{z}^{2}} \\
& I=\tan ^{-1} \frac{H_{z}}{\sqrt{H_{x}^{2}+H_{y}^{2}}} \\
& D=\tan ^{-1}\left(\frac{H_{y}}{H_{x}}\right)
\end{aligned}
$$

Magnetic declination is the arctangent of $H_{y} / H_{x}$ with respect to separate quadrants (Eq. 3). Parameters $H_{x}, H_{y}$ $\mathrm{H}_{\mathrm{z}}$ represent the magnetic field components.

In the laboratory, $2 \times 2 \times 2 \mathrm{~cm}$ rock cubes were cut from massive and sunburn rocks. Natural remanent magnetization (NRM) and isothermal remanent magnetization (IRM) were measured for all samples. The IRM was acquired by MMPM10 pulse magnetizer in a 1T field. Both NRM and IRM were measured by spinner magnetometer JR6 (Agico). The REM (remanent magnetization) parameter was calculated as a NRM proportional to the total remanent magnetization that rock could acquire; the total is represented by IRM saturated by the field $1 \mathrm{~T}$ :

$$
R E M=\frac{N R M}{I R M}
$$

The chemical composition of titanomagnetite controls the magnetic behaviour of the rock. Especially Ti, Al and $\mathrm{Mg}$ lower Curie temperature and increase fielddependent magnetic susceptibility (Schnabl et al. 2010). Field dependence of susceptibility was measured over the range of 10-300 A.m ${ }^{-1}$ and frequency $2000 \mathrm{~Hz}$ using a Kappabridge AGICO susceptibility meter KLF-4. The field dependence was quantified as $k_{H D}$ that was defined by Vahle and Kontny (2005):

$$
k_{H D}=\frac{k_{300}-k_{30}}{k_{300}} 100,
$$



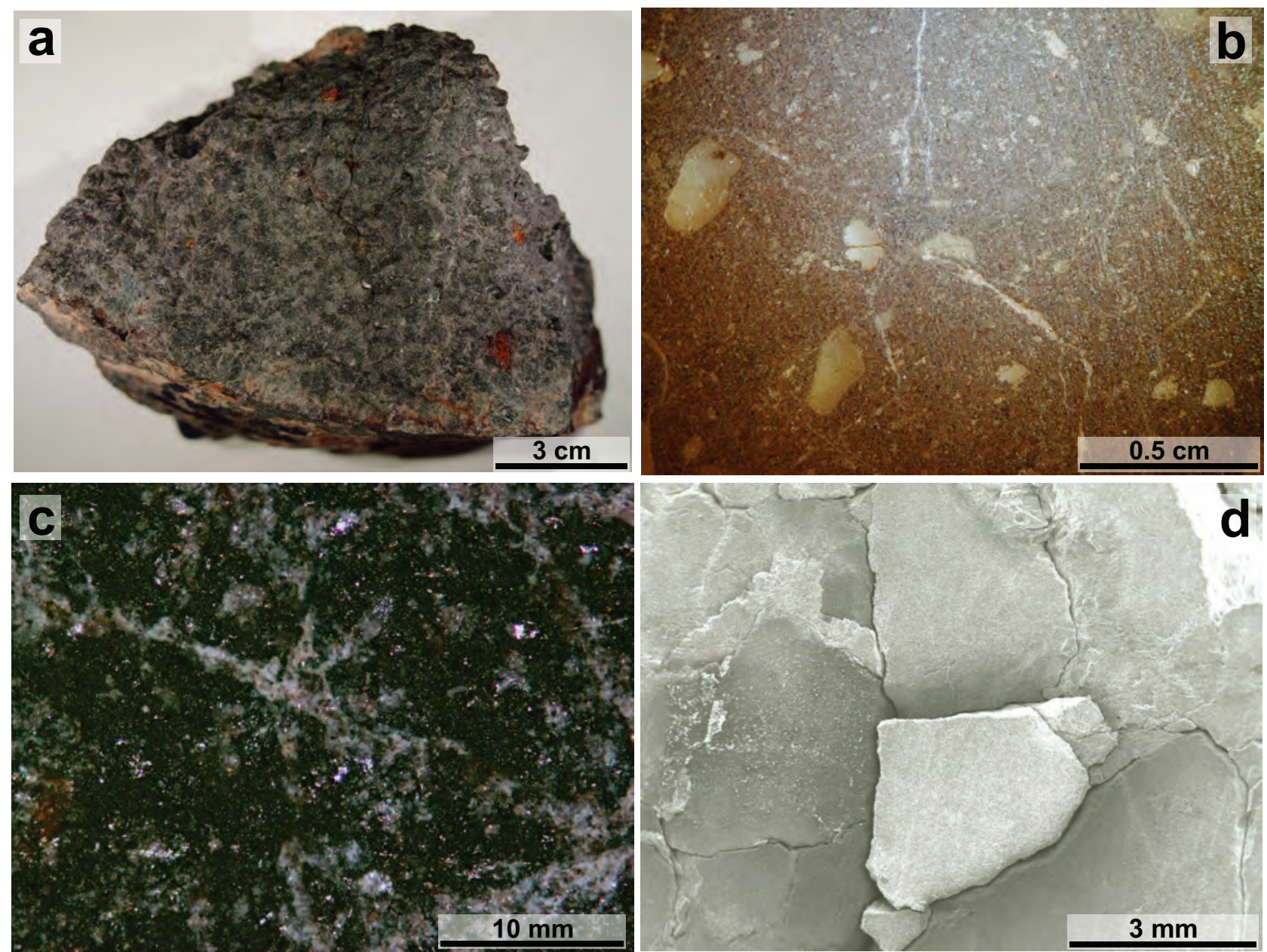

Fig. 2 The sunburn effect from macro to micro scale. a - Macro photograph of the sample, spots are clearly visible; b Macro photograph of capillary cracks and analcite minerals; c-Spots and "white sun" under the optical microscope with plane-polarized light; d - Cracks captured by SEM.

where $k_{x}$ is the susceptibility measured in the magnetic field with amplitude expressed in A. $\mathrm{m}^{-1}$.

A Kappabridge AGICO KLY-4 coupled with a temperature-control unit CS-3 was used for measurement of the temperature dependence of magnetic susceptibility from room temperature up to $700^{\circ} \mathrm{C}$ (Hrouda 1994). The measurements were carried out with a field of $300 \mathrm{~A} . \mathrm{m}^{-1}$ and frequency of $875 \mathrm{~Hz}$. The powdered samples were heated in an argon atmosphere with a rate of $c .10^{\circ} \mathrm{C} / \mathrm{min}$. Curie temperatures were identified using inverse susceptibility as proposed by Petrovský and Kapička (2006).

\section{Results}

\subsection{Petrographic analysis}

The sunburn effect from macro to micro scale is shown in Fig. 2. At two of the localities, the lavas differ only by the degree of sunburn effect. The remaining mineralogy of the observed rocks is rather constant over the outcrop.
At the third locality however, we observed a significant variation in petrography.

\subsubsection{Borská Skalka near Nový Bor, Czech Republic $\left(50^{\circ} 46^{\prime} 28^{\prime \prime} \mathrm{N}, 14^{\circ} 32^{\prime} 42^{\prime \prime} \mathrm{E}\right)$}

Lavas from Borská Skalka represent typical basanites, common in the Lausitz Volcanic Field. The rock is porphyric in texture (Fig. 3a-b); phenocrysts account for $\sim 10$ vol. $\%$ and are composed of olivine up to $1 \mathrm{~mm}$ and clinopyroxene up to $3 \mathrm{~mm}$ across. Clinopyroxenes are always zoned with sometimes greenish cores and a pale margin (green-core pyroxenes).

Microlites (100 to $300 \mu \mathrm{m}$ in size) are olivine, clinopyroxene, plagioclase and titanomagnetite. In the groundmass, we also observed nepheline and alkaline feldspars. Glass is present, mostly in between microlites. Small amounts of analcite, the mineral that is responsible for the sunburn effect, were observed even in the massive lavas, forming radial aggregates of small needles (Fig. 3c). 

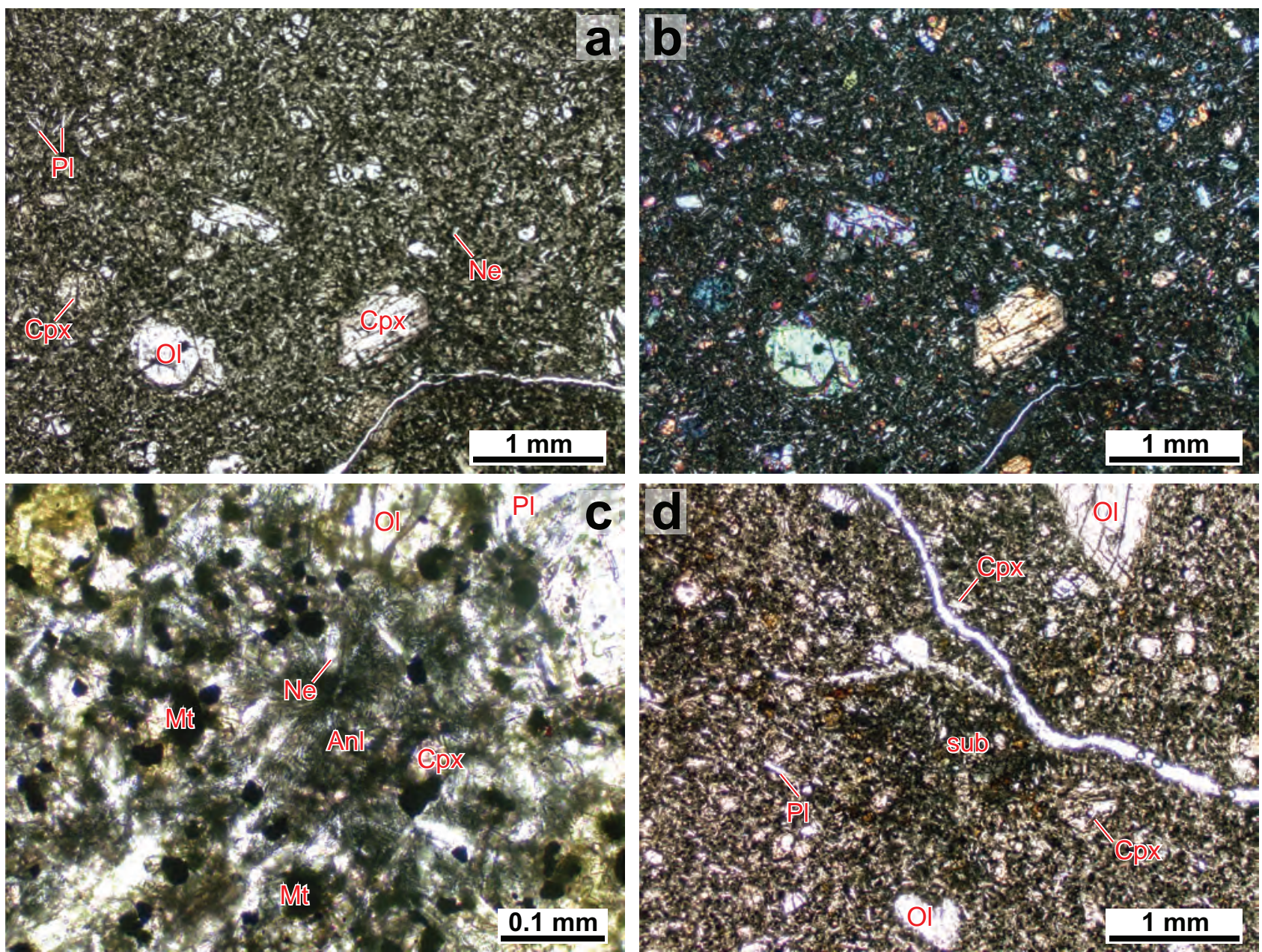

Fig. 3 Photomicrographs of rocks from Borská Skalka. a-b Porphyric texture of fresh, unaffected basanite (plane-polarized light $=$ PPL and cross-polarized light); c - Initial analcite crystallization as small needles, PPL; d - Advanced analcite growth in spots (darker parts) inducing cracking, PPL. Anl $=$ analcite, $\mathrm{Cpx}=$ clinopyroxene, $\mathrm{Ne}=$ nepheline, $\mathrm{Pl}=$ plagioclase, $\mathrm{Ol}=$ olivine, $\mathrm{Mt}=$ Magnetite, sub $=$ sunburn.

The analcite appears first in between microlites. From there the mineral is seen to grow in spots dispersed throughout the rock volume.

This initial stage of analcite growth can be observed mostly in the massive, fresh lavas as well as in the transition zone with the altered ones. In sunburn lavas, small prisms of analcite overgrow all other minerals around the spots. Cracks open from spots of analcite growth (Fig. 3d). We have studied several parts of the sample to determine the chemical composition of the rock. The appearance of analcite is indicated by the enhanced amounts of $\mathrm{Al}$

Fig. 4 Spectrum of EDS analysis from Borská Skalka, sunburn part. and $\mathrm{Na}$ (see the EDX spectrum of the sunburn part given in Fig. 4).

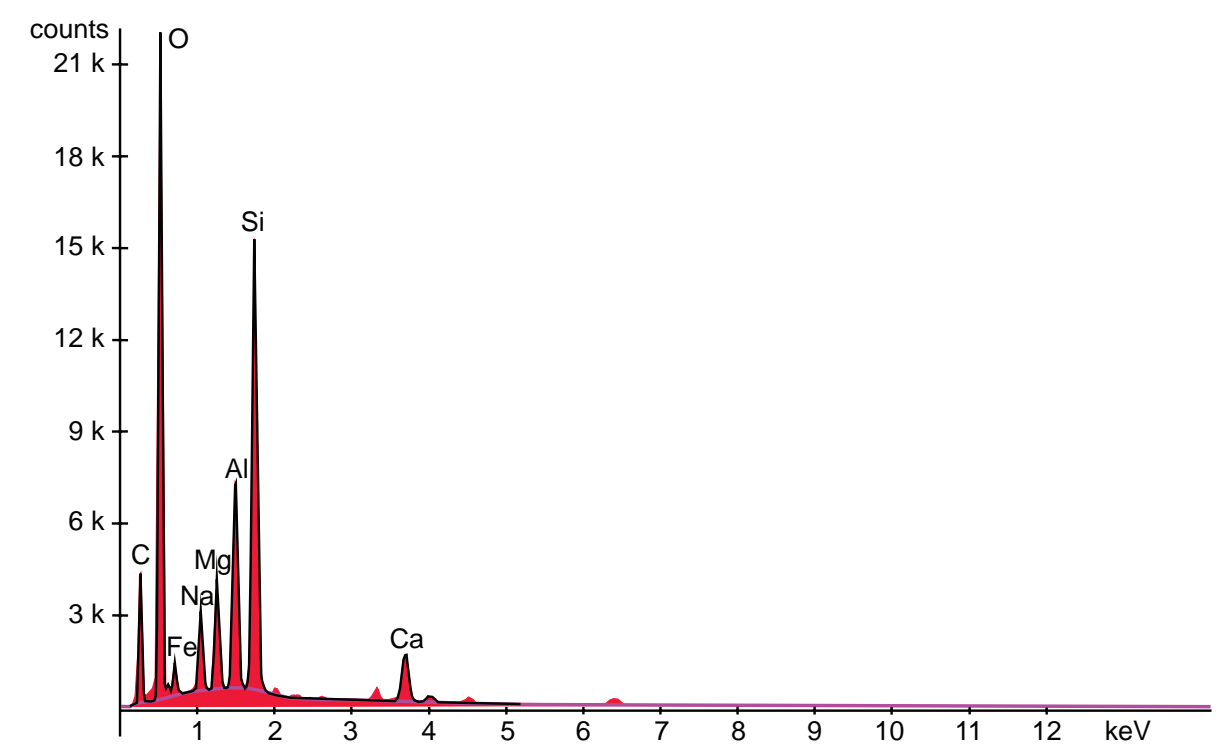



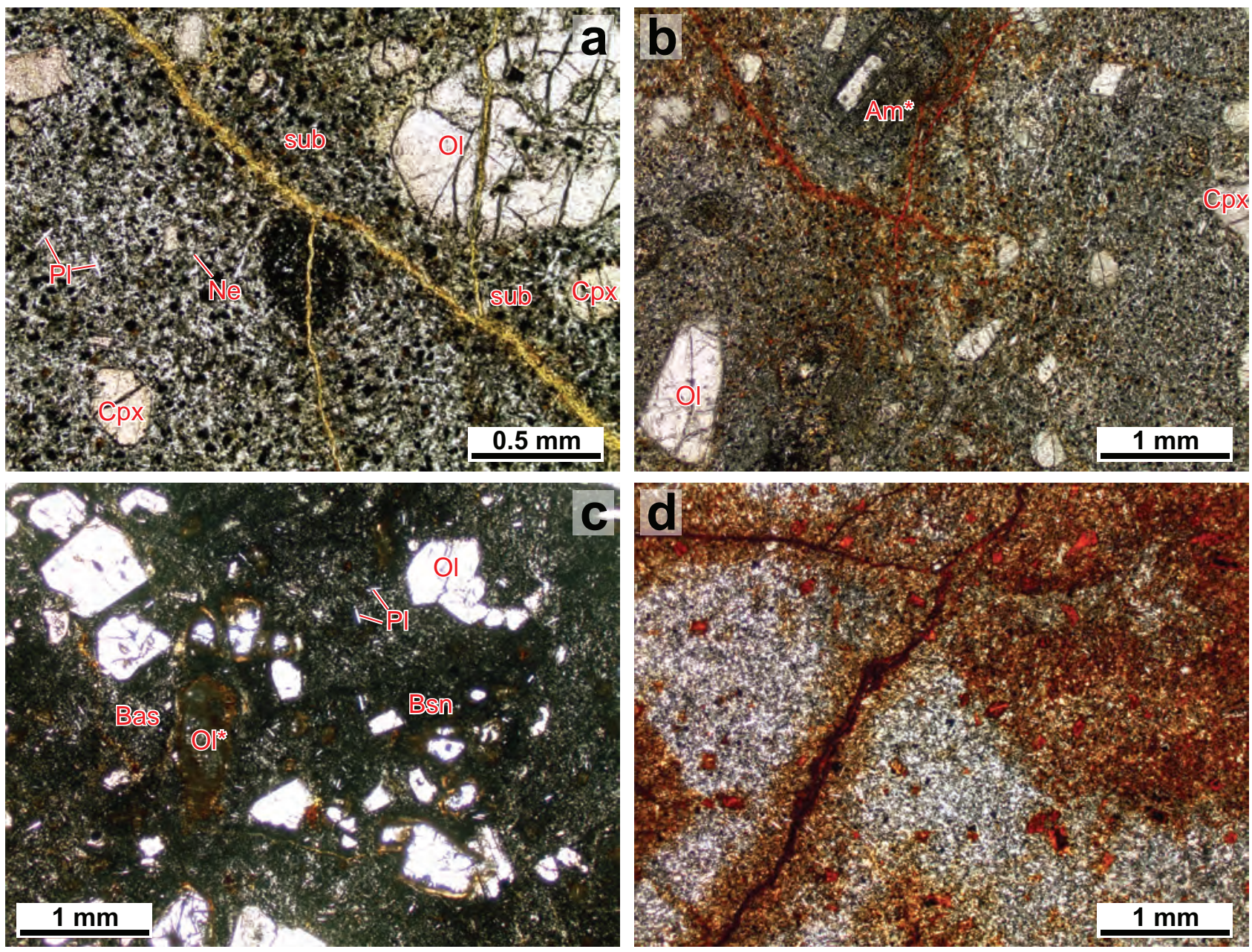

Fig. 5 Photomicrographs of rocks from Mittelherwigsdorf and Wittgendorf. a - Analcite "spots" (darker parts) in between unaffected lava, Mittelherwigsdorf, PPL; b - Limonite infiltrating sunburn spots, Mittelherwigsdorf, PPL; $\mathbf{c}$ - "Schlieren" of basanitic lava in basalt of Wittgendorf, PPL; $\mathbf{d}$ - Groundmass of sunburn basalt filled with limonite, Wittgendorf, PPL. Abbreviations correspond to Fig. 3 except for Am* = weathered amphibole, $\mathrm{Ol}^{*}=$ weathered olivine, $\mathrm{Bas}=$ alkali basalt, $\mathrm{Bsn}=$ basanite

\subsubsection{Active quarry Scheibenberg near Mittelherwigsdorf, Germany $\left(50^{\circ} 54^{\prime} 49^{\prime \prime} \mathrm{N}, 14^{\circ} 43^{\prime} 38^{\prime \prime} \mathrm{E}\right)$}

The lavas are mainly porphyric tephrites with fine-grained matrix. Fine-grained lavas are dominated by opaque minerals (probably magnetite), clinopyroxene and nepheline. The shape of the minerals is mostly prismatic or elongated along the phenocrysts with a size up to $5 \mathrm{~mm}$. They seem to be pseudomorphs after amphiboles whose small remnants occur rarely in the centres of the aggregates. Additionally, pseudomorphs of larger crystals of the same size as the clinopyroxenes occur. Microlites are mainly clinopyroxene and plagioclase, occasionally nepheline and titanomagnetite. We observed the same minerals in the groundmass. Samples show different analcite contents, which is seen as darker spots (Fig. 5a). Cracks in the rock radiate from these spots of analcite nucleation, as in the Borská Skalka lavas. In this locality, the cracks are always filled with limonite. Limonite also infiltrates the sunburn spots, which have many microcracks (Fig. 5b).

\subsubsection{Abandoned quarry north of Wittgendorf, Germany (5057'20"N, $\left.14^{\circ} 50 ' 31 " \mathrm{E}\right)$}

In thin section, fresh rocks are mostly porphyric and have an alkali basalt mineralogy. Phenocrysts are formed by olivine and clinopyroxene, both up to $4 \mathrm{~mm}$ in size. Olivine is partly altered and iddingsite fills the cracks in the crystals. Microlites are plagioclase and titanomagnetite. The groundmass is composed of glass. However, several parts contain schlieren-like patches of basanitic composition that appear darker and have less plagioclase (Fig. 5c). Additionally, nepheline was detected in the groundmass.

Sunburn is limited to the prevalent alkaline basalt lavas, whereas basanites show no alteration. Sunburn lavas 


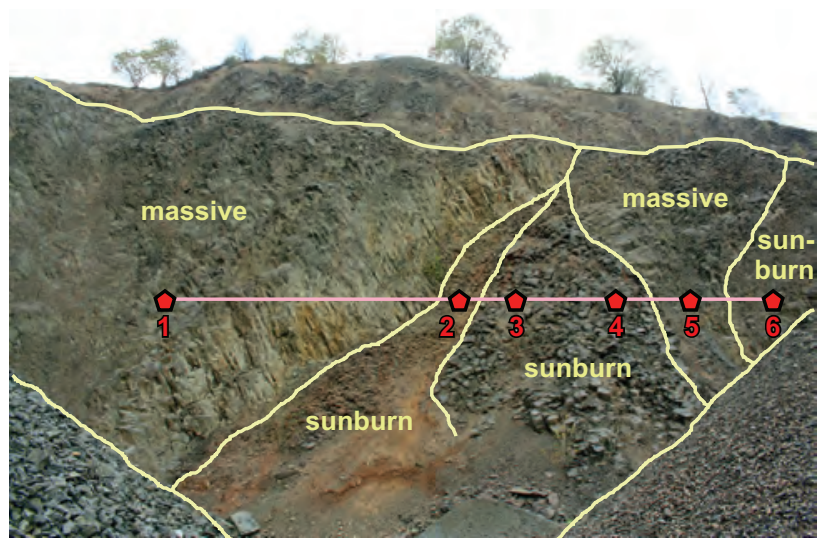

Fig. 6 Sketch of the Mittelherwigsdorf quarry wall with positions of sunburn and massive basalts marked. Red pentagons show the location of profile and number of the profile.

are finer grained and with a composition of olivine-bearing alkali basalt. They are microlithic and no nepheline is visible under the microscope. Moreover, all olivines and the rare clinopyroxenes, which are microlites, are intensively weathered and contain cracks filled with limonite. Also, the whole rock is affected by many cracks filled by limonite and much of the groundmass is infused by the same mineral (Fig. 5d), Thus, the petrography of matrix is obscured. The pattern of cracks in the lava resembles that of the two other locations.

\subsection{Magnetic analysis}

\subsubsection{Field measurements}

Thirteen magnetic profiles were measured at the three localities where sunburn basalts occur. The sections were always perpendicular to the rock face. The localities were selected according to the different geomorphological shape of the basaltic body, such as a cellular hill or a single rock tower. At Mittelherwigsdorf, the sections were situated more than $30 \mathrm{~m}$ below the top of the hill (Fig. 6). The Wittgendorf sections were located in a quarry $4 \mathrm{~m}$ below the top of a flat table mountain. At the Borská Skalka site, the sections were $10 \mathrm{~m}$ below the top of a prominent rock tower (Fig. 7) with a lightning rod missing its earth wire.

The intensity of the magnetic field and its azimuth change with the distance from the rock. Magnetic inclination does not vary much $\left(\sim 5^{\circ}\right)$ except for the Borská Skalka site (Fig. 7), where the inclination change exceeds $40^{\circ}$ (Fig. 8) (Electronic supplementary material, ESM 1).

At Mittelherwigsdorf, the standard deviation of the magnetic field is $0.12-0.23 \mu \mathrm{T}$, the azimuth changes up to $3.6^{\circ}$, except for the last section, passing through the most sunburnt part of the volcanic body. The standard

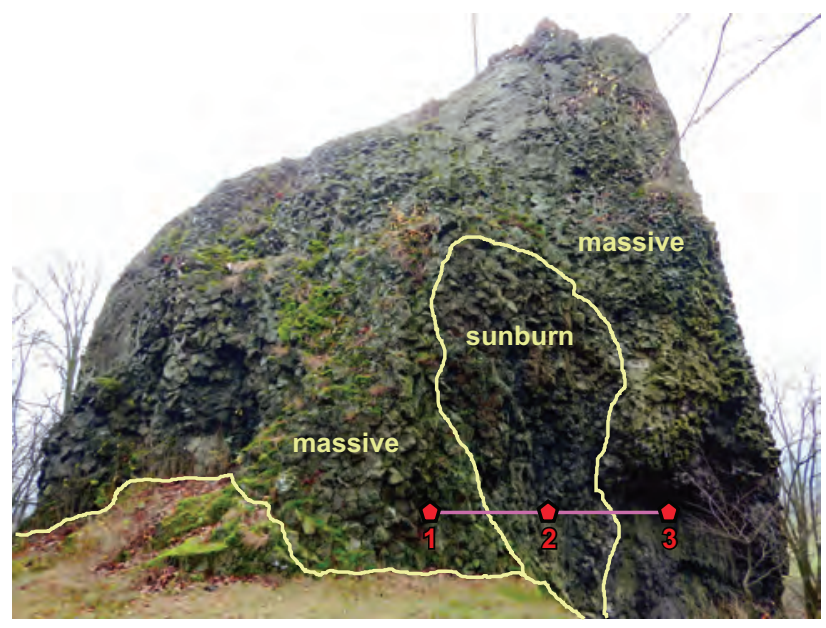

Fig. 7 Sketch of Borská Skalka with the positions of sunburn and massive basalts indicated. Red pentagons show the location of profile and number of the profile.

deviation of declination is $6.8^{\circ}$. The important changes occurred within $20 \mathrm{~cm}$ from the outcrop wall (Fig. 8).

At Wittgendorf, the changes in the magnetic field along the profiles were higher for the sunburnt part than the massive ones. Significant changes are also recorded in close proximity of the rock; however, for the sections WD1 and WD3 the major anomalies occur $\sim 1.3 \mathrm{~m}$ from the rock surface. This anomaly could be explained only by the morphology of the quarry (Fig. 8). The standard deviation of the magnetic field is $1.1-3.4 \mu \mathrm{T}$, and of declination $1.2-4.9^{\circ}$.

Borská Skalka sections yielded significant changes in magnetic intensity and azimuth in both sections. For sunburn part, the standard deviation of the magnetic field is $29.3 \mu \mathrm{T}$, and of the azimuth $78.7^{\circ}$. For the massive part, the standard deviation of the magnetic field is $2.1 \mu \mathrm{T}$, of the azimuth $7.8^{\circ}$. The major change in magnetic field is $30 \mathrm{~cm}$ away from the rock-wall face for both, sunburned and massive rock. However, the intensity of magnetic field varies more around the sunburn part than around of the massive rock (Fig. 8).

\subsubsection{Laboratory measurements}

Magnetic parameters - natural remanent magnetization (NRM), isothermal remanent magnetization (IRM) and remanent magnetization (REM) were obtained for all samples (Tab. 1).

Natural remanent magnetization ranges 2.2-8.9 A.m ${ }^{-1}$ for massive, and 2.6-59.9 A.m ${ }^{-1}$ for sunburn basalts. Isothermal remanent magnetization after acquisition at $1 \mathrm{~T}$ varies from 654.5 to 871.1 A.m ${ }^{-1}$ in massive, and from 415.0 to 1004.5 A.m ${ }^{-1}$ in sunburn basalts. Remanent magnetization is mostly higher for sunburn basalts (0.3-14.4 $\%$ ) than for massive types ( 0.3 to $1.4 \%)$. Generally, the 

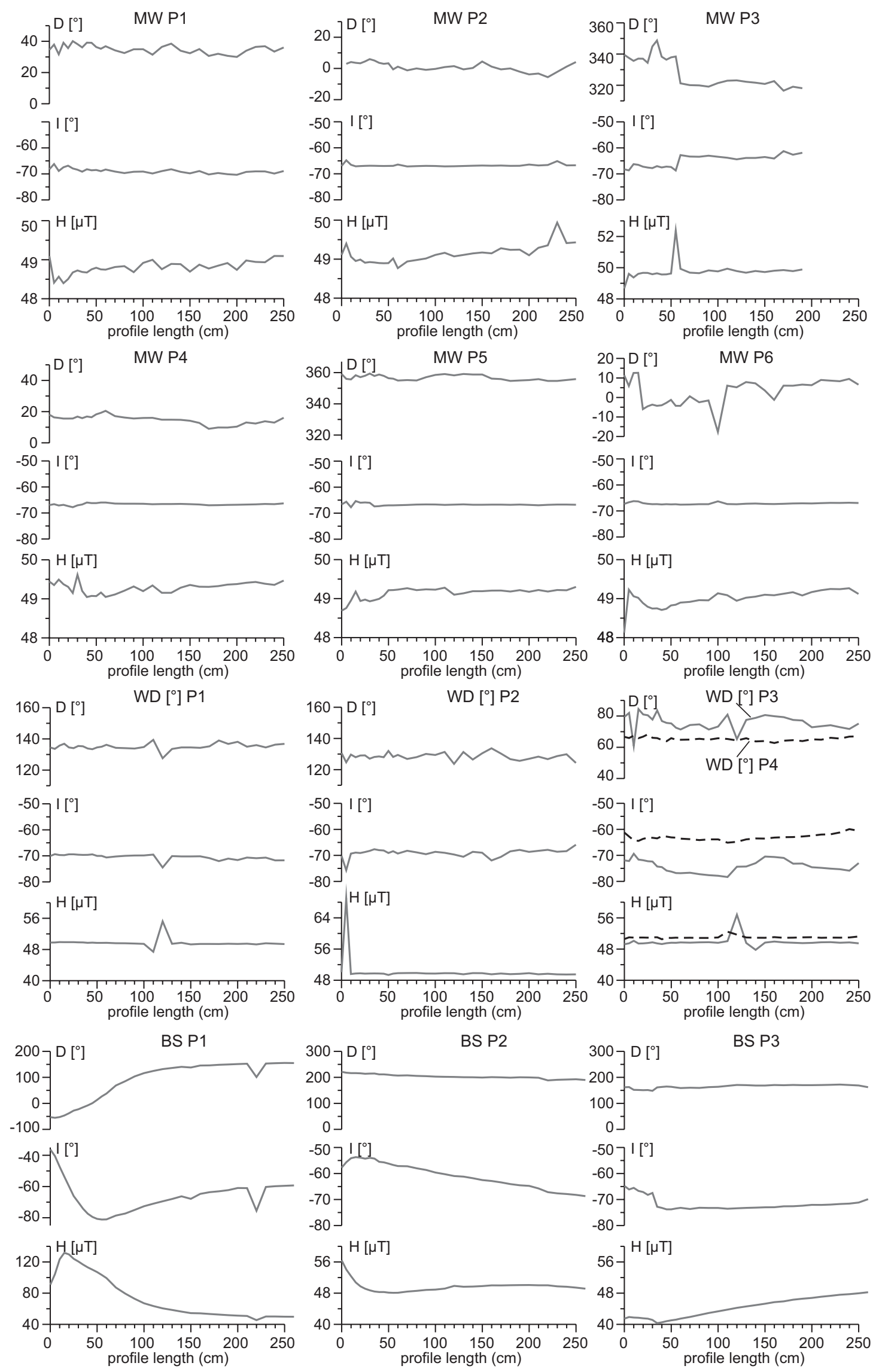
Tab. 1 List of localities with measured magnetic parameters

\begin{tabular}{lcccc}
\hline Locality & Rock type & IRM [1T] & NRM [A.m $\left.{ }^{-1}\right]$ & REM [\%] \\
\hline MW1 & massive & 798.148 & 8.726 & 1.093 \\
MW2 & sunburn & 861.448 & 11.502 & 1.335 \\
MW3 & sunburn & 1004.475 & 7.679 & 0.765 \\
MW4 & sunburn & 704.632 & 6.452 & 0.916 \\
MW5 & massive & 654.502 & 8.919 & 1.363 \\
MW6 & sunburn & 551.766 & 9.290 & 1.684 \\
WD1 & massive & 871.122 & 4.164 & 0.478 \\
WD2 & sunburn & 985.514 & 2.648 & 0.269 \\
WD3 & sunburn & 942.017 & 19.132 & 2.031 \\
WD4 & massive & 666.103 & 2.223 & 0.334 \\
BS1 & massive & 730.000 & 4.070 & 0.558 \\
BS2 & sunburn & 415.000 & 59.870 & 14.427 \\
\hline
\end{tabular}

Localities: MW = Mittelherwigsdorf, $\mathrm{WD}=$ Wittgendorf, $\mathrm{BS}=$ Borská Skalka

highest values for all parameters were obtained at Borská Skalka locality.

\section{Discussion}

Petrographically, the lavas do not differ between two of the investigated localities (Borská Skalka and Mittelherwigsdorf). The mineralogical composition of sunburn rock is similar to that of fresh rocks, i.e. there is no significant change in the nature or amount of magnetic minerals over the whole locality. The most important differences of sunburn from fresh rocks are (1) the content of analcite instead of amorphous glass in the cryptocrystalline matrix and (2) the presence of variably sized cracks probably induced by analcite recrystallization, filled with secondary minerals like limonite. The limonite also occurs throughout the rock. Phenocrysts are partly weathered in sunburn samples and are also filled with limonite. Thus, we suggest that the sunburn phenomenon is related to the differences in the magnetic measurements. The sunburn parts of the outcrops contain more moisture than the massive rock. This moisture increases the electric conductivity and channels lightnings preferentially, leading to modification of the magnetic properties.

The most prominent changes in all the variables could be seen at Borská Skalka, where the outcrop top is directly exposed to lightning. The lowest changes occurred in rocks at Mittelherwigsdorf that are furthest from the top of the hill. The possible lightning strikes are already grounded and only a small amount of electric discharge can possibly enhance the magnetization of the rock around the sunburn zone.

Fig. 8 Graphs for the profiles measured at Mittelherwigsdorf, Wittgendorf and Borská Skalka. MW P1, MW P5: massive rocks, MW P2-MW P4: sunburn rocks, WD P1, WD P4: massive rocks, WD P2-WD P3: sunburn rocks, BS P1: sunburn rock, BS P2- BS P3: massive rocks.

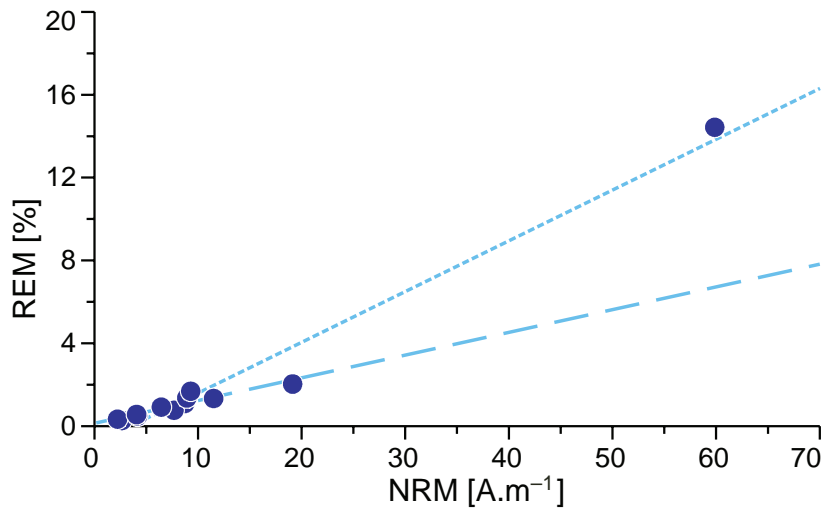

Fig. 9 Binary plot of NRM vs. REM parameters. The finely-dashed trend is computed from all measured data, the coarsely dashed line was fitted disregarding one outlying measurement.

Wittgendorf site is four meters below the very top, which means that the magnetic field and the azimuth could have been affected by lightning. However, the main change at the profiles WD P1 and WD P3 occurred c. $130 \mathrm{~cm}$ away from the wall, which implies that the major cause of this particular inhomogeneity (see Fig. 8) could be explained only by the morphology of the quarry wall and/or some metal artefact in the scree or hidden nail in a tree trunk.

Even though the parameter REM is not extremely high, the intensity of the magnetic field $(H)$ is. The highest value was measured for the most affected sunburn rock at Borská Skalka. Both NRM and REM parameters are higher for sunburn rocks; nevertheless, parameter IRM remains constant. The dependence of NRM vs. REM is displayed in Fig. 9. Two trend lines are fitted, including and excluding the last data point with extreme value.

Measurements of the Curie temperature and fielddependent magnetic susceptibility of the rock (Fig. 10, Tab. 1) proved that the sunburn effect did not change the magnetic properties and therefore we can assume that there were no significant changes in the chemical composition of titanomagnetite. An increase in goethite (major magnetic carrier component of limonite, detected under the optical microscope) contents was not found by these methods, because goethite is several orders of magnitude less magnetic than titanomagnetite.

All magnetic results indicate that the sunburn basalt is more magnetic (higher natural remanent magnetization, remanent magnetization) than the massive basalt. However, we do not observe strong mineralogical changes between fresh and sunburn lavas except of the secondary overprints by analcite and limonite. Thus, the magnetic anomalies are most probably lines induced by lightnings. Lightning paths are favoured along sunburn affected zones because of increased water content also contained in analcite. 

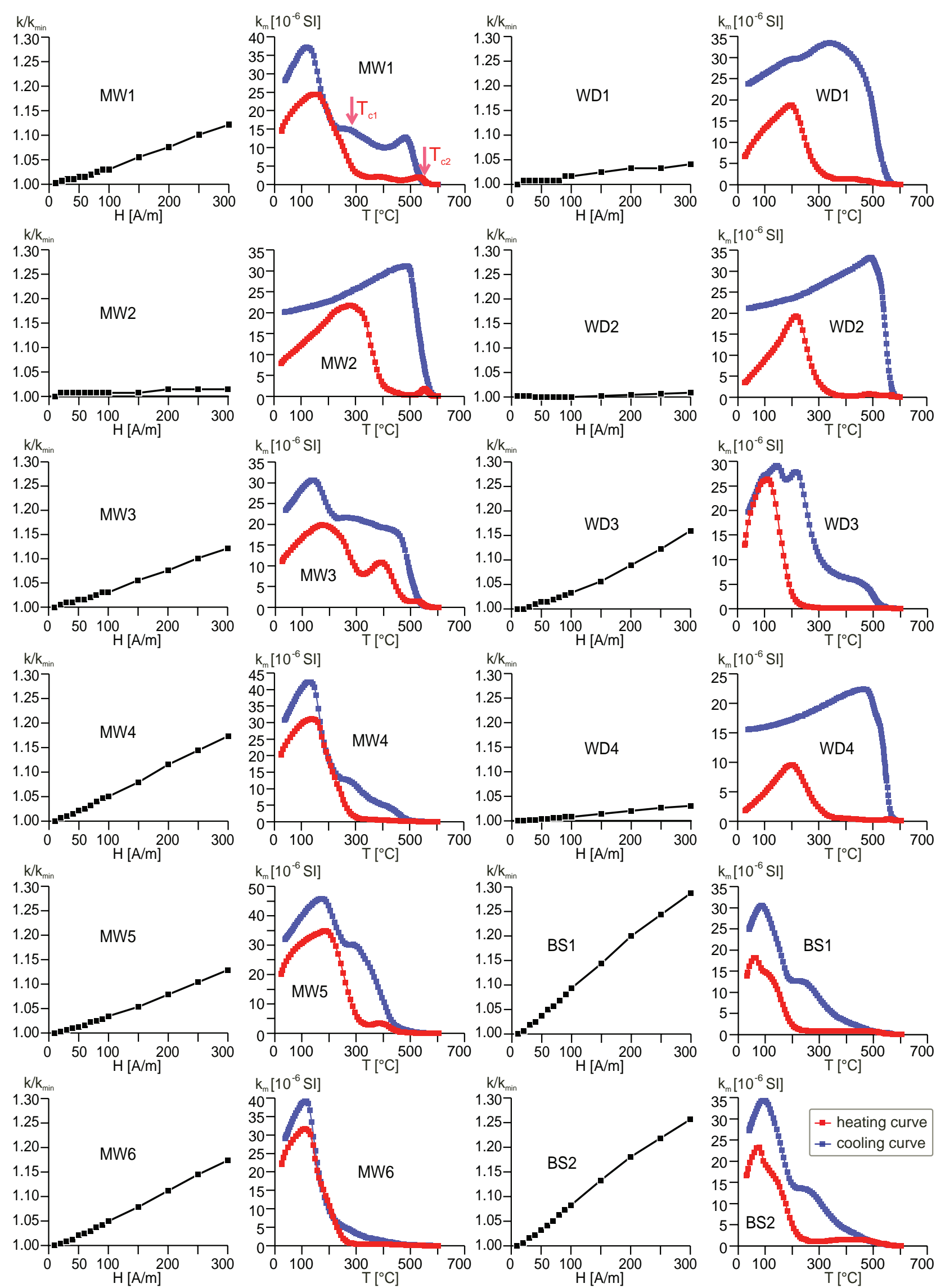


\section{Conclusions}

Sunburn textures are found in lavas with a composition of olivine-bearing alkali basalt to basanite. Analcite, the mineral that is responsible for the sunburn effect, was found in all studied samples. Cracks in the rock, the starting points for the growth of analcite spots, are usually filled with limonite. Limonite also infiltrates the sunburn spots that are strongly microcracked. The changes in the magnetic field intensity along profiles measured perpendicular to the volcanic bodies were higher for the sunburn parts than for the massive basalts. The greatest changes were recorded in close proximity of the rock; however, in cases, they were several centimetres away. This anomaly was caused by the morphology of the volcanic body. The measured IRM [1T] ranged 666.1-871.1 A.m $\mathrm{A}^{-1}$ for massive and 551.8-1004.5 A. $\mathrm{m}^{-1}$ for sunburn basalts. On average, the sunburn basalts show higher NRM (2.6-59.9 A. $\left.\mathrm{m}^{-1}\right)$ and REM $(0.3-14.4 \%)$ than the massive ones (2.2-8.9 A.m ${ }^{-1}$ and $0.3-1.4 \%$, respectively). Hence, the sunburn basalts are affected by changes in mineralogy (increasing secondary mineral contents), microtexture, and magnetic properties of the rocks. The changes are caused by weathering and hydration. Therefore, the sunburn parts become lightning paths and the primary magnetic data are overprinted.

In general, results of both field and laboratory measurements have been influenced by the sunburn, and thus care should be taken to avoid such zones when studying basalts. Further comparison with fresh rocks could clarify the chemical changes the lavas undergo due to sunburn creation and resulting weathering. However no changes in the composition of the main carrier of magnetization (titanomagnetite) were found in this work (based on Curie temperature and field-dependent susceptibility).

Acknowledgements. We are indebted to our friends and colleagues who helped us with both field and laboratory analyses, namely L. Borecká, M. Kř́žzová, B. Mlčoch, G. Nikoloupoulos, J. Petráček, Z. Skácelová, A. Šulc, and F. Wilke. We wish to thank Joachim Härtel and Fabian Lange from the BASALT AG who permitted the measurements in the active quarry Mittelherwigsdorf. This work has been supported by IRSM CAS (AVOZ30460519) for L. Nováková and GLI CAS (RVO67985831) for P. Schnabl. We thank Michael S. Petronis and an anonymous reviewer for their helpful and constructive reviews.

Fig. 10 Measurements of the Curie temperature (heating and cooling curves) and field-dependent magnetic susceptibility of the rocks from Mittelherwigsdorf, Wittgendorf and Borská Skalka. Examples of two Curie temperatures $T_{c 1}$ and $T_{c 2}$ detected on a single sample are indicated by arrows.
We also thank to Handling Editor B. van Wyk de Vries and Editor in Chief V. Janoušek for final improvements.

Electronic supplementary material. Supplementary table of the field data for all measured profiles in the studied localities is available online at the Journal web site (http://dx.doi.org/10.3190/jgeosci.274).

\section{References}

BüChNeR J, TIETZ O (2012) Reconstruction of the Landeskrone scoria cone in the Lusatian Volcanic Field, Eastern Germany - long-term degradation of volcanic edifices and implications for landscape evolution. J Geomorp 151-152: 175-187

Büchner J, Tietz O, Viereck L, Abratis M, Stanek KP, SUHR P, PFÄNDER JA (2013) The Lusatian Volcanic Field - link between the Ohře Rift and the Eastern European volcanoes. In: BÜCHNER J, RAPPRICH V, TIETZ O (eds) Basalt 2013 - Cenozoic Magmatism in Central Europe, Görlitz, 24-28 April 2013. Abstracts \& Excursion Guide. Czech Geological Survey, Prague, pp 72-73

Büchner J, Tietz O, Viereck L, Suhr P, Abratis M (2015) Volcanology, geochemistry and age of the Lausitz Volcanic Field. Int J Earth Sci 104: 2057-2083

Butler RF (1992) Paleomagnetism. Blackwell Scientific Publications, Boston, MA, pp 1-319

CAJZ V (2000) Proposal of lithostratigraphy for the České středohoří Mts. volcanics. Bull Geosci 75: 7-16

CAJZ V, Rapprich V, ERban V, PÉCSKay Z, Radoñ M (2009) Late Miocene volcanic activity in the České Středohoří Mountains (Ohře/Eger Graben, northern Bohemia). Geol Carpath 60: 519-533

Fediuk F (2003) Principal directions and asymmetrical zoning of Cenozoic volcanics in the Lužické hory Mts. and the adjacent area, N Bohemia. Geolines 15: 28-34

Gisbert G, Aulinas M, Garcia-Valles M, Fernandez D, Gimeno D, ZAGożdżon P (2016) Petrological and geochemical characterization of sunburns in alkaline basaltic rocks. IX Congreso Geológico de España. GeoTemas 16: 455-458 (in Spanish with English summary)

HibSCH JE (1920) Über den Sonnenbrand der Gesteine. Z prakt Geol 28: 69-78

Hrouda F (1994) A technique for the measurement of thermal changes of magnetic susceptibility of weakly magnetic rocks by the CS-2 apparatus and KLY-2 Kappabridge. Geophys J Int 118: 604-612

Kaiser G, Pilot J (1986) Weitere K-Ar-Datierungen an jungen Vulkaniten. Z geol Wiss 14: 121-124

KoPECKÝ L (2010) České Středohoří Mts and Ambient Young Alkaline Volcanic Complexes in the Ohře Rift, Czech Republic: Volcanology, Petrology and Rift Evolution. Czech Geological Survey, Prague, pp 1-188 
KüHnel RA, VAn Der GaAst SJ, Brych J, LAAn GJ, Kulnig H (1994) The role of clay minerals in durability of rocks: observations on basaltic rocks. Appl Clay Sci 9: 225-237

LEPPLA A (1901) Über den sogenannten Sonnenbrand der Basalte. Z prakt Geol 9: 170-176

Lorenz V, Suhr P, Goth K (2003) Maar-Diatrem-Vulkanismus - Ursachen und Folgen. Die Guttauer Vulkangruppe in Ostsachsen als Beispiel für die komplexen Zusammenhänge. Z geol Wiss 31: 267-312

Lustrino M, WiLsOn M (2007) The circum-Mediterranean anorogenic Cenozoic igneous province. Earth Sci Rev 81: $1-65$

Pfeiffer L, Kaiser G, Pilot J (1984) K-Ar Datierungen von jungen Vulkaniten im Süden der DDR. Freiberg Forsch-H R C 389: 93-97

Petrovský E, KapičKa A (2006) On determination of the Curie point from thermomagnetic curves. J Geophys Res 111: B12S27

Pukall K (1939) Beiträge zur Frage des Sonnenbrandes der Basalte. I. Z Angew Min 1: 195-222

Pukall K (1940) Beiträge zur Frage des Sonnenbrandes der Basalte. II. Z Angew Min 2: 277-303

Schnabl P, Novák JK, Cajz V, Lang M, Balogh K, PÉcskay Z, Chadima M, Šlechta S, Kohout T, Pruner P, ULRYCH J (2010) Magnetic properties of high-Ti basaltic rocks from the Krušné hory/Erzgebirge Mts. (Bohemia/ Saxony), and their relation to mineral chemistry. Stud Geophys Geod 54: 77-94

SCHREIBER U (1991) Basaltic "Sonnenbrand", the result of magmatic assimilation of incorporated surface sands, and magma mixing phenomena: the alkaline volcanic association of Westerwald region, Western Germany. In: PAČESOVÁ MJ (ed) Symposium on Central European Alkaline Volcanic Rocks (SCEAVR), Abstracts. Charles University, Prague

Schreiber U, Anders D, Koppen J (1999) Mixing and chemical interdiffusion of trachytic and latitic magma in a subvolcanic complex of the Tertiary Westerwald (Germany). Lithos 46: 695-714

Suhr P, Goth K, Lorenz V, SuHr S (2006) Long lasting subsidence and deformation in and above maar-diatreme volcanoes - a never ending story. Z geol Wiss 157 : 491-511

ŚLIWA Z (1975) Genetic types of minute fissility in basalts and its bearing on the quality of produced chips. Acta Univ Wratisl Pr Geol Miner 247: 211-233 (in Polish with English abstract)

Tietz O, Büchner J, Suhr P, Abratis M, Goth K (2011a) Die Geologie des Baruther Schafberges und der Dubrauker Horken - Aufbau und Entwicklung eines känozoischen Vulkankomplexes in Ostsachsen. Ber Naturforsch Ges Oberlausitz, Suppl 18: 15-48
Tietz O, GÄRTner A, Büchner J (2011b) The monogenetic Sonnenberg scoria cone-implications for volcanic development and landscape evolution in the Zittauer Gebirge Mountains since the Paleogene. Z geol Wiss 39: 31-334

Tietz O, Büchner J, Suhr P, Goth K (2013) Field trip 3: Volcanology of the Lusatian Volcanic Field - new insights in old well-known. In: BüCHNER J, RAPPRICH V, Tietz O (eds) Basalt 2013 - Cenozoic Magmatism in Central Europe, Görlitz, 24-28 April 2013, Abstracts \& Excursion Guide. Czech Geological Survey, Prague, pp 275-297

Ulrych J, Pivec E, Lang M, Balogh K, KropáčeK V (1999) Cenozoic intraplate volcanic rock series of the Bohemian Massif: a review. Geolines 9: 123-129

Ulrych J, Dostal J, Adamovič J, Jelínek E, Špaček P, Hegner E, BAlogh K (2011) Recurrent Cenozoic volcanic activity in the Bohemian Massif(Czech Republic). Lithos 123: 133-144

Vahle C, Kontny A (2005) The use of field dependence of AC susceptibility for the interpretation of magnetic mineralogy and magnetic fabrics in the HSDP-2 basalts, Hawaii. Earth Planet Sci Lett 238: 110-129

Vavrová J, Kraus I, OndrášiK M (2002) The influence of clay minerals on properties of volcanic rocks of the Western Carpathians used for building industry. Miner Slov 34: 289-302

Wedepohl KH, Baumann A (1999) Central European Cenozoic plume volcanism with OIB characteristics and indications of a lower mantle source. Contrib Mineral Petrol 136: 225-239

Weiner B, Lehrberger G, Thuro K (2007) Petrophysical properties of sunburn basalt from the upper palatinate in north-eastern Bavaria. In: Отто F (ed) 16. Tagung für Ingenieurgeologie und Forum "Junge Ingenieurgeologen", Bochum 2007. DGGT, Bochum, pp 77-87 (in German with English summary)

Wimmenauer W (1974) The alkaline province of central Europe and France. In: Sørensen H (ed) The Alkaline Rocks. Willey, London, pp 238-271

ZAGOŻDŻON P (1998) Characteristics of the sonnenbrand basalt from Winna Góra near Jawor (SW Poland). Przegl Geol 46: 1171-1178 (in Polish with English summary)

ZAGOŻDŻON P (2001a) On the origin of basaltic sunburn. Przegl Geol 49: 328-334

ZAGOŻDŻON P (2001b) Sunburn in Tertiary Basaltoids of Silesia and the Possibilities of Utilizing Them. Unpublished Ph.D. Thesis, Politechnika Wrocławska, Wroclaw, pp 1-122 (in Polish)

ZAGOŻDŻON P (2003) Sunburn in the Tertiary Basalts of Silesia (SW Poland). Geolines 15:188-193 